DEPÓSITO LEGAL ZU2020000153

Esta publicación científica en formato digital

es continuidad de la revista impresa

ISSN 0041-8811

E-ISSN 2665-0428

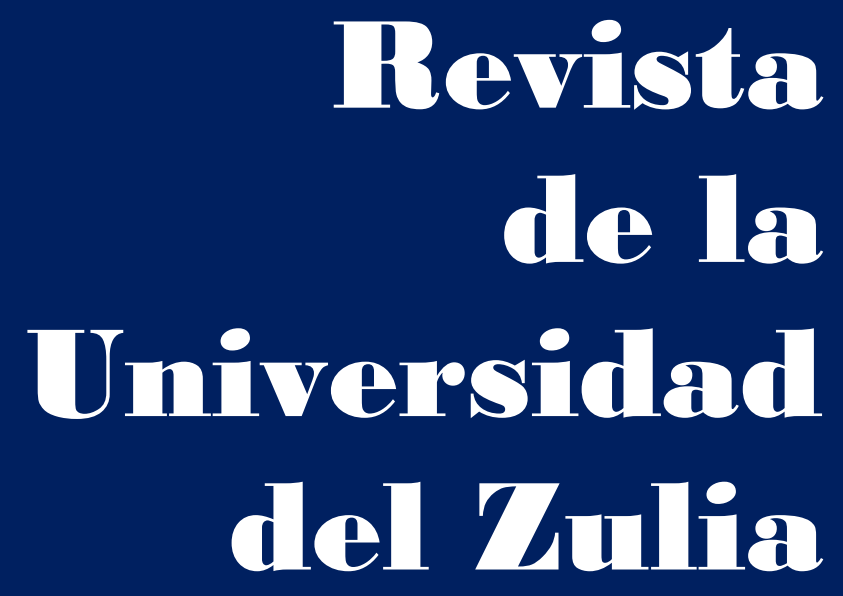

Fundada en 1947

por el Dr. Jesús Emrique Lossada

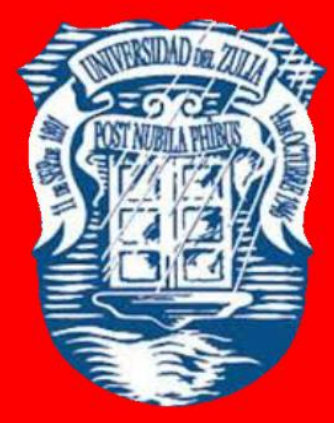

Ciencias

Sociales

y Arte

Año $12 \quad N^{\circ} 34$

Septiembre - Diciembre 2021

Tercera Época

Maracaibo-Veneruela 


\title{
The influence of a passionate personality on the preservation of the ethno-cultural code of society in Eastern countries
}

\author{
Anara G. Shabambaeva * \\ Zadash O. Dukenbaeva ** \\ Khanif S. Vildanov *** \\ Aipova Ainash **** \\ Temirgalinova Assel $* * * *$
}

ABSTRACT

The authors consider new approaches to the study of the role of the passionate personality in the development of the countries of the East. The authors consider the socio-political and scientific activities of the scientist A. Zh. Mashanov as a passionary from the point of view of influence on the ethno-cultural code of the Kazakhs. The concepts of "historical process" and "political process" are clarified; the relationship between history and politics is revealed. The verbal-paraverbal methods of $\mathrm{A}$. Zh. Mashanov in political activity are shown. The contribution of the scientist as a driving force during the historical process is revealed and described the role of the scientist as a catalyst for the spiritual revival of Kazakhstan in connection with the relentless struggle for the study of al-Farabi's creativity as a cultural and spiritual source is determined.

KEY WORDS: historical personality; political personality; totalitarian and authoritarian regimes; East; democracy.

*Doctoral student, Eurasian National University. L.N. Gumilyov, Nur-Sultan, st. Satpayev, 2. ORCID: https://orcid.org/000-0003-3663-1368

**Doctor of Historical Sciences, Professor, Eurasian National University. L.N. Gumilyov, NurSultan, st. Satpayev, 2. ORCID: https://orcid.org/0000-0002-5968-1539

***Doctor of Philosophy, Professor, Head of the Department of Philosophy, History and Social Engineering, Ufa State Petroleum Technical University, Russia. ORCID: https:/orcid.org/0000$\underline{0003-3230-2348}$

****Doctoral Candidate in the specialty "Pedagogy and Psychology», Senior lecturer, S. Toraighyrov Pavlodar State University, Kazakhstan. ORCID: https:/orcid.org/0000-0002-8428$\underline{8018}$

*****Doctoral Student in the specialty 6D010300 «Pedagogy and Psychology», S. Toraighyrov Pavlodar State University, Lomov str., 64, Pavlodar, Kazakhstan. ORCID: https://orcid.org/00000001-9202-1885

Recibido: 05/05/2021

Aceptado: 08/07/2021 


\section{La influencia de una personalidad apasionada en la preservación del código etnocultural de la sociedad en los países de Oriente}

RESUMEN

Los autores consideran nuevos enfoques para el estudio del papel de la personalidad apasionada en el desarrollo de los países de Oriente. Los autores consideran las actividades sociopolíticas y científicas del científico A. Zh. Mashanov como un apasionado desde el punto de vista de su influencia en el código etnocultural de los kazajos. Se aclaran los conceptos de "proceso histórico" y "proceso político"; se revela la relación entre historia y política. Se muestran los métodos verbales-paraverbales de A. Zh. Mashanov en la actividad política. Se revela la contribución del científico como fuerza impulsora durante el proceso histórico y se describe el papel del científico como catalizador para el renacimiento espiritual de Kazajstán en relación con la lucha implacable por el estudio de la creatividad de al-Farabi como fuente cultural y espiritual.

PALABRAS CLAVE: personalidad histórica; personalidad política; regímenes totalitarios y autoritarios; Oriente; democracia.

\section{Introduction}

Modern ethnopolitical processes are closely related to changes in the conceptual picture of the world, reflecting the dynamics of language and culture in the chronotope. The media design of countries is directly dependent on the historical process, which is a sequential change in the states of nature, society and intelligence in time and space during world development (Tyurina, 2019). A modern researcher of media texts sees that it is the anthropogenic factor, considering its "many-sidedness", that determines the linguistic picture of the world of the modern media space.

The purpose of the article is to study A. Zh. Mashanov as a historical and political personality who took an active part in historical and political processes, in connection with which it is assumed to reveal the concepts of "historical process", "political process", to establish a connection between them, to characterize A. Zh.Mashanov as a certain type of historical and political personality, to identify the motives of the scientist's participation in historical and political activities. 
The idea of returning to the cultural and historical traditions of the people was raised in the works of many scientists and thinkers in different countries. This aspect is especially important for the countries of the East, which are strong in their tradition of continuity and reverence for the teacher as such. However, a Kazakh folk proverb says: "And a seventy-yearold elder will come to bow to a seven-year-old boy, if he comes from a long journey." Therefore, in Eastern countries there is a special attitude to passionate personalities who change the course of the historical process. Kazakh scientist-encyclopedist A. Zh. Mashanov made a huge contribution not only to various fields of science and culture of Kazakhstan, but also to the socio-political life of the Kazakh society. It was A. Zh. Mashanov who was one of the first who created religious studies in Soviet Kazakhstan. He promoted the philosophical ideas of Al-Farabi to revive interest in the cultural heritage of the past, which became the impetus for the creation of a new science - Farabi studies. A. Zh.Mashanov considered the cultural and historical heritage of the peoples of Central and Central Asia in the aspect of the passionarity of Asian peoples and their desire to conquer large spaces. In this regard, the analysis of the personality of A. Zh. Mashanov as a significant historical and political personality is natural and relevant in the new conditions of establishing the ethno-political identity of the countries of the post-socialist world.

At the same time, P. K. Goncharov characterizes the political process as a process "taking place in the sphere of politics, reflecting the dynamic, mobile, constantly changing side of the political system of society" (Goncharov, 2018). These processes are interrelated, since the historical process is a more voluminous concept that includes, as an integral part, the political system and the changes taking place in it. The historical process has a complex structure that includes several components. D. Easton believes that the political process acts as a part of the social system, defining it as "the continuous functioning and change of the political system of society" (Easton, 1977: 630-631). As a result of intensive influence on the addressees of our discourse, we find the transformation of "ethnocultural and sociocultural matrices of behavior" (Karabulatova et al, 2017:7).

Selected, critically thinking individuals are the guiding star of the development of history, since they are associated with special spheres of activity in society - the sphere of spiritual production and the management system (Kazakov, 2017). 
So, studying the personality of a politician, a leader of opinions, we can talk about his influence on changing the political process in the country, about his promotion of transformations of the historical process. This is expressed in the fact that the opinion leader influences the change during politics aimed at the spiritual revival of society. In his article "A Look into the Future" N.A. Nazarbayev drew attention to the restoration of the national code, the study of the historical past, indicated clear worldview guidelines (Nazarbayev, 2017). In this programmatic article, N.A. Nazarbayev showed himself as a historical and political personality, influencing the change in state policy - the modernization of the public consciousness of citizens through the spiritual revival of experience. The very return to the traditional value-semantic orientations and the spiritual heritage of the people becomes the cultural and historical nucleus of the formation of the national identity of the ethnos and plays an important role in the formation of citizenship of young states in the era of linguisticmental wars and Post-Truth.

The relevance of the problem of studying the phenomenal personality and his role in the advancement of historical and political processes is due to a change in the methodological paradigms of the study of historical processes. Earlier, in the study of history, the objective laws of social development were brought to the fore, which were identified with the outpersonality and unconsciousness of the historical process, the main emphasis was not on individual originality, originality, and uniqueness of the personality itself, but on the concentration in it of typical features and characteristics of a representative of one or another. a different class. Today, the task of humanizing history as a science, its "humanization", increased attention to the role of the individual in history is especially acute.

\section{Theoretical aspects}

The history is not a fatal, faceless process, but a complex and contradictory phenomenon, in which not only large masses of people participate, but also individual personalities, especially outstanding personalities, who leave the imprint of their bright and unique individuality on the entire course of events. In this regard, one of the important aspects of the knowledge of history is the disclosure of the question of the nature and degree of influence of an individual (ordinary, talented, outstanding, brilliant) on the course of historical events. 
However, the thinkers of antiquity already knew that it is most convenient to do this on the examples of the activities of great personalities - rulers, generals, "heroes", etc. Hence, for example, in Ancient Rome, works that solved this problem on an empirical level were so popular: "Comparative Biographies" of Plutarch," The Life of the Twelve Caesars " by Gaius Suetonius Tranquillus," On the conspiracy of Catilina " by Gaius Sallust Crispus, etc. Later in the XIX century, the outstanding role of the individual in history was recognized (based on certain theoretical positions) by such thinkers as T. Carlyle, F. Nietzsche, G. Lebon and others. As a result, historians, and philosophers of the XX century also began to be interested in the personalities of the leaders (rulers).

The problem of the role of the individual in history has been posed in ancient Eastern and ancient historiography, philosophical thought. In the European tradition, it was mainly solved by ancient Greek (Herodotus, Thucydides) and ancient Roman (Plutarch, Gaius Suetonius Tranquille, Gaius Sallust Crispus, Quintus Curtius Rufus) historians at the empirical level. Thinkers extracted individual "lessons" from the actions of specific historical characters (Croesus, Themistocles, Pericles, Alexander the Great, Pompey, Gaius Julius Caesar, Nero, etc.), revealing the mistakes they made during practical activity, blamed bad deeds, etc. However, the first theoretical questions were already raised here: what place does the ruler occupy in the political hierarchy (Meng-tzu); is he an independent ruler of history (Thucydides) or a weak-willed "toy" of external forces (Herodotus); is it possible to prevent negative actions of rulers (Rufus)? (Sidney Hook 1963).

Thus, the role of the individual in history is studied within the framework of various disciplines: historical science, sociology, political science, cultural studies, etc. Hence, it is necessary to identify the place of this problem in the philosophy of history, its influence on other issues considered here; to establish the specifics (features) of its consideration in this section of philosophical knowledge.

\section{Materials and methods}

We see the need to use an interdisciplinary approach based on combining different approaches: anthropocentric, historical, and socio-cultural. This will assist in revealing the intrinsic value of a person in the historical process, in identifying and describing the measure of the personality's influence on changes in the political process in the country, will help to 
define and describe the typology of an outstanding personality, to characterize the motives and various aspects of her activities, which have left noticeable traces that contribute to changing the course of history and changes in political processes in the country.

The diverse and interdisciplinary nature of the problems of value attitudes of choosing a significant historical person in the formation of new value attitudes in the countries of Central Asia determines the variety of various sources used in the work.

This is a contradictory result of the activities of successive generations with their own aspirations, hopes and expectations.

The methodological basis of the dissertation consists of several consistently applied means of cognition: analysis and synthesis; system, comparative, structural and functional analysis; the method of ascent from the abstract to the concrete; the civilizational approach; the theory of paradigms by T. Kuhn (1957).

Research methods: in the course of the research, the methods of biographical analysis (based on the testimony of witnesses, the restoration of facts from the life of the individual), the anthropological method (it is assumed to identify the peculiarities of the national character of the individual), the synergetic method (aimed at studying the political side of the country, the socio-political system of the individual as a self-organizing system, which is characterized by dynamism, instability, leading to a change in the political process) are used.

Therefore, the purpose of this article is to identify the role of A.Zh. Mashanov in promoting the political process at critical moments in the development of the state, assisting them in changing the state of society at one time or another of its functioning. To achieve this goal, it is necessary to solve the following tasks:

- Mashanov as a historical person;

- the significance of the scientist's activity in the political aspect;

- the role of Mashanov in promoting political and historical processes in the country; - socio-political ideas, ethical views, views and moral values of the scientist.

To describe a scientist as a certain type of political personality, methods of anthropocentric, biographical analysis and a method of modeling are used. The essence of the anthropocentric approach is to study the influence of a person's national character and the type of his mentality on his political behavior, which is actualized in the process of influencing the course of the political process. To do this, one should first identify the type 
of personality of a scientist who takes an indirect or direct part in political activity. The classification of policy actors is carried out in different ways. The classification of the personality of a politician proposed by M. Weber is widely known.

These questions can be considered based on the published epistolary heritage of A. Zh. Mashanov.

The authors consider the published scientific works and speeches of the scientist in the periodical press. In addition, we used the available archival materials.

The participation of the individual in the course of history lies in his actions aimed at the development of the historical process. These include the scientist's historical research: 1) the creation of historical works: "On the study of the heritage of al-Farabi", "Aristotle of the East", "Great scientists of Central Asia and Kazakhstan", "Al-Farabi and Abai", etc .; 2) the publication of scientific research in the mining and mineralogical sciences - according to the method of searching for minerals, several gold deposits were discovered (Nurpeisova, 2016), copper-pyrite ores, the publication of more than 80 scientific works devoted to the development of mining; 3) study of the ancient history of Kazakhstan. In his books "Secrets of the Earth" (Almaty, 1948), "The Structure of the Earth" (Almaty, 1949), "The Mystery Enclosed in Stone" (Almaty, 2006), the scientist describes the way of life of ancient people who inhabited the territory of Kazakhstan (central and eastern regions), the ways of their economic activities, types of crafts, introduced readers to their beliefs, expressed his thoughts about the stone statues found on this earth.

\section{Results and discussion}

The mystical connection exists as a given and a person cannot know it. Outstanding personalities, huge masses of people, entire peoples, historical epochs are just tools of the world mind, which secretly and secretly controls them and implements its goals through them.

Akzhan Zhaksybekovich Mashanov is considered one of the founders of geomechanics in the Soviet Union. As a passionary of the Kazakh society, he promoted his ideas through Kazakh popular science fiction. A. Zh. Mashanov is the ancestor of Kazakh science fiction. His novels such as "Journey into the Depths of the earth", "The Secret of the Earth" have gained special popularity. A. Zh.Mashanov is also known as a historian-researcher, especially as a 
popularizer of the ideas of Al-Farabi. The multifaceted talent of A. Zh. Russian Russian and Russian - Kazakh dictionaries on mining, geology and metallurgy, a researcher of the scientific heritage of the great scientist of the East al-Farabi, was also manifested in his original scientific field-both Kazakh-Russian and Russian-Kazakh dictionaries on mining, geology, and metallurgy (Nurpeisova, 2016).

Akzhan Mashanov (Mashani) was a surprisingly versatile and talented person, his long and fruitful life was almost always connected with one university - the Kazakh Mining and Metallurgical Institute, now it is the Kazakh State National University named after K. I. Satpayev.

In 1939, A. Mashanov graduated with honors from the university with a degree in mining engineer-geologist. In the same year, he became the first graduate student of this institute. Even the Second World War could not tear A. Zh. Mashanov away from geological exploration because he understood the military strategic importance of minerals. In 1943, A. Zh. Mashanov successfully defended his PhD thesis "The structure of the Turgay ore field", in 1945 he published a scientific monograph "Fundamentals of a new methodology for studying the structure of ore fields". Just three years later, in 1946, A. Zh. Mashanov defended his doctoral dissertation "Study of the structure of ore fields by the method of subsurface geometry". A new look at the problem field of science provided a high level of A. Zh. Mashanov's reputation capital, and in 1946 A. Zh. Mashanov became one of the initiators of the opening of the Academy of Sciences of the Republic of Kazakhstan (Nurpeisova, 2016).

A. Zh. Mashanov personally participated in the discovery of the AkbastauKusmurinsky, Leninogorsky, Zyryanovsky, Torgaysky, Zhezkazgan and Karatau deposits. The versatility of the scientist's life interests was provided by encyclopedic knowledge, as well as rich scientific erudition. A. Zh. Mashanov was able to capture new scientific and pedagogical ideas, successfully using them in his activities. The results of Akzhan Mashani's in-depth research have become widely known abroad. Deep knowledge in the field of geology, mathematics, geometry, mechanics, and mining allowed him to create a new scientific direction in mining - geomechanics (Tuleubaev, 2006).

A wide scientific outlook, knowledge of the Arabic language allowed Akzhan Zhaksybekovich to do one of his main things - opening the role of the great scientist Abu Nasir al-Farabi to the world (Nysanbaev, 2011). A. Zh.Mashanov proved that the origins of 
the culture and science of Kazakhstan were the works of al-Farabi, thereby the name of this great scientist was forever entered into the history of science of the Republic of Kazakhstan. For the in-depth research of al-Farabi's legacy, Arab scientists assigned him a new surname al-Mashani. By the decision of UNESCO, 2006 was declared the year of the centenary of alMashani. East Kazakhstan State Technical University named after D. Serikbayeva was the organizer of the scientific forum, where the prospects for the development of mining and geological affairs in Kazakhstan were discussed. Akzhan Mashani devoted his life to this (Nysanbaev, 2011).

The essence of the personalist paradigm is revealed by the following theses: a) the activity of an individual cannot be completely determined by objective factors of the historical process; b) any trend of social development bears the imprint of a certain historical figure (i.e. it is personified); c) the "replacement" of a historical personality is not neutral. It can lead to both positive and negative consequences.

It is known that a passionate personality plays the role of a transformer of ideological, ethnosocial and cultural matrices in society. This problem is of the utmost importance today because the multipolar world is balancing on the edge, each time choosing new points of support (Khachmafova et al, 2017: Parra Contreras, 2020). The problem of determining A.Zh. Mashanov to this or that type of personality is one of the intractable since the scientist carried out many-sided fruitful activities in many spheres of public life. There is no doubt that the encyclopedic scientist belongs to the elite type of personality (Ostrovskaya et al, 2015), since he left significant traces in the field of mining, astronomy, theolinguistics, made a significant contribution to the development of translation studies and literature.

In the Western and Eastern philosophical traditions, the essence of the tendency to mythologize (sacralize) a historical person is reduced to endowing it with supernatural qualities. At the level of scientific knowledge, it has found a complete expression in the concept of the "charismatic personality" by M. Weber. Personality desacralization is the process of considering it as an ordinary person with high creative abilities or broad powers of authority. In the latter case, the qualities of such a person established in European philosophical thought are revealed: cruelty, purposefulness, cunning, restraint of emotions.

Particularly noteworthy is the selfless activity of the scientist in the historical and political spheres of public life. This led to global changes in socio-political attitudes and 
changes in the ethnosocial and cultural consciousness of the population (Grushevskaya et al, 2018). Thus, the attribution to a historical person is due to his performance of actions that affect events of a historical nature.

L.E. Grinin refers to the historical personality of the individual in the case when "due to his personal characteristics, or chance, or social position, or the specifics of the time, any person can show by the very fact of his existence, his ideas, his ideas, action or inaction , directly or indirectly, during his life or in the period after his death, such impacts on his own or other people's societies, which can be considered important, since they left a noticeable mark in history and influenced the course of the further development of societies (positively, negatively or unambiguously not definable) "(Grinin, 2017).

The participation of an individual in the course of history lies in his actions aimed at the development of the historical process (Nurpeisova et al., 2006).

According to D.S. Zhahiyayly, A.Zh. Mashanov, in the process of studying ancient monuments (balbals), tried to decipher the rock carvings, described the features of the ancient system of the Huns and Saks (Zhakhiyakly, 2018, electronic resource), cited evidence that some cities: Jun-Bulen (Junn), Gun-Guan (Gunn ), Hua (Donghu), located on the territory of modern Mongolia and China, are Turkic (Mashanov, 2006); 4) scientists have thoroughly studied the history of medieval Kazakhstan (the history of the Karkaralinsky and Bukeevsky khanates and their rulers), studied stone statues in the Sary-Arka region. According to the testimony of M.B. Nurpeisova, B.M. Zharkimbenov, Baigurin, the historian A.Zh. Mashanov collected information about the stone statues of Sary-Arka, carried out excavations of medieval structures (Nurpeisova et al., 2006). He carried out archaeological research and compared them with the data of the ethnocultural code of the region.

In the Karagailly tract, he dug up two (Turkic) enclosures with statues (Mashanov, 2006). It is noteworthy that A.Zh. Mashanov tried to interpret archaeological sites using his knowledge in the field of astronomy (Kasenova, 2019).

Within the framework of the theory of driving forces, a historical person can act as such a force, and is characterized as one of the most important among them. The passionate personality acts as a driving force, affirming by its existence the idea that the future can change because of the activities of not only large political forces, but even individual groups 
and their leaders, it also depends on the actions of a variety of people, for example, scientists (Zimina, 2009).

The merit of the scientist A. Zh. Mashanov is that he played a significant role in determining the direction of the political process in the future of post-Soviet Kazakhstan. This goal was served by his socio-political ideas regarding the study of the creative heritage of al-Farabi, which A. Zh. Mashanov expressed back in 1959. In the process of tireless creative search, selfless activity, the scientist set himself the task in 1956: to start researching the legacy of al-Farabi. In 1960, the scientific initiative of A.Zh. Mashanov was supported by the President of the Academy of Sciences of the Kazakh SSR K.I. Satpayev, who imposed a resolution on the scientist's memo on the need to study the legacy of al-Farabi "I agree. Implement" (Central State Archives of the Republic of Kazakhstan, fund 2285, inventory 1, file 152).

All the activities of A. Zh. Mashanov can be considered as a window of discourse (or the so-called Overton Window), which shifts the bifurcation point of assemblage of personality and society, first acting as a potentially dangerous discourse, and then acting as a potentially desirable discourse of development (Karabulatova, 2020) ... For example, A.Zh. Mashanov, on his own initiative, "traveled in the footsteps of al-Farabi to the grave of a scientist in Damascus" (Central State Archives of the Republic of Kazakhstan, fund 2285, inventory 1, file 152). According to A. Mashanov, "being a lone scientist, my father began to correspond with the libraries of Syria, Turkey, London, Stockholm, and others. At his expense, photocopies of the works of Eastern scholars were sent to him. Investigating these sources, my father constantly expanded the circle of searches" (Mashanov, 2017: 297). In search of materials on the work of al-Farabi, the scientist repeatedly traveled to Syria (Damascus, Sham and other cities). During 35 years devoted to the study of al-Farabi, scientists have published more than 20 articles, published monographs: "Great scientists of Central Asia and Kazakhstan" (Almaty, 1969), "On the translation of al-Farabi's works into Kazakh language" (Almaty, 1969), "Farabi and education of youth" (Almaty, 1972), "AlFarabi" (Almaty, 1970), "Al-Farabi zhane Abay" (Almaty, 1994), "Al-Farabi and modern sciences" (Almaty, 2007).

A. Derbisaliev noted the great role of A. Mashanov in the development of the course of history. This role was as follows: the scientist, even though al-Farabi entered the history of 
Arab culture, managed to prove to the whole world the Turkic origin of the great thinker, returned him to his homeland, published many books dedicated to al-Farabi of historical significance, waking up thereby our sleeping spirit" (Derbisaliev, 1996).

As you can see, A.Zh. Mashanova belongs to this type of historical personality, which, according to Z. Hook's classification, actively influences events. Z. Hook in his theory of personality divides historical figures into people who influence events and people who create events (Hook, 1993).

The study of the personality of A.Zh. Mashanov as a political subject that influenced the change in the political process.

M. Weber identified three types of personality of a politician. He attributed to the first type those individuals who are engaged in politics "on occasion", when a person occasionally makes an expression of his will, without thinking about the nature of political actions. The second type is a person who is constantly engaged in professional political activity. The third type of politician is an individual who is involved in politics "in combination" (Weber, 1990).

Typically, researchers classify policy actors on the basis of participation or nonparticipation in politics. At the same time, persons with political status are distinguished, as well as social communities (classes, nations, political elites). The second group includes states and public organizations (Gorbunova, 2012; Shulman, 2015). The third classification of a political personality is based on the allocation of such political personalities as a political subject and a political person. A political person in the narrow sense is understood as a person who acts in politics as a leader, a politician, a person involved in politics (Shcheglov, 2012).

A political subject is specifically a political bearer of a variety of political activities aimed at conquering, protecting or using power in order to realize vital interests. The totalitarian regime itself compelled to select linguistic means so that the author could promote his ideas using metaphorical models of euphemization and windows of discourse (Vorozhbirova et al, 2019; Weber 1990; Malevinsky et al, 2019).

The fourth classification of a political personality is determined by the type of political participation. N. Baranov proposed a model of the political participation of a subject in the political process: a) a model of political participation, when there is a balance of relationships between political participants, civil influence, and power structures; b) a model of political 
participation, when the state only partially reacts to the will of citizens. Here, political participation is curtailed, limited; c) formal participation, a model of political participation that creates only the appearance of mass activity of the population; adaptive participation, when forced to show loyalty to the political regime. This model was improved and refined by E.S.Adulova (2009).

Determination of the personality type A.Zh. Mashanov, based on political personalities identified in the above classifications, shows that the scientist can be attributed to the personality of a politician "by chance", since the main activity of A.Zh. Mashanov is associated with his scientific, educational, and pedagogical activities. He turned to politics "on the occasion", when it was necessary to defend ideas related to the implementation of the idea of national policy to protect the cultural heritage of al-Farabi. His participation in politics is limited, since he does not actively participate in political activities, but to a certain extent affects the change in the political process in the country.

The effectiveness of the synergetic approach in the study of socio-political ideas A.Zh. Mashanov lies in the possibility of considering the system of the worldview of a scientist as a self-organizing open system capable of undergoing changes. E.S. Adulova, analyzing the synergetic specifics of the evolution of modern political processes, believes that "complete stability and balance in society is stagnation, dead ends of the process, when the flow and use of external and internal resources becomes constant. Society is becoming an authoritarian, not an open system. At the same time, a controlled instability, a small revolutionary, in its essence, reform can act as a condition for a stable, dynamically developing society (Adulova, 2009: 19).

The goal of the political process was to ensure deterministic stability and constancy in the political sphere in the era of the totalitarian regime and the opposition of regimes in the information war (Barabash et al., 2019), while the scientific, journalistic and media discourses were clearly regulated to cover any material from the position of "We and Other"(Karabulatova, Lyausheva et al., 2018). Thus, during the functioning of the Soviet state, the history of the people and their culture were consigned to oblivion. In the political sphere, communist ideology prevailed. In the period from 1921-1953. totalitarianism manifested itself in the fact that "the state represented by the Communist Party played a huge role in the life of society, striving to control all spheres of its life through the created system of mass 
organizations (Pioneer, Komsomol organizations, trade union committees, local committees, women's councils, associations of scientists, artists, athletes, etc. etc.) (Petrov, 2011; Vorozhbitova et al., 2019). During the reign of N.S. Khrushchev and L.I. Brezhnev, an authoritarian regime took place (1955-1980), from 1989 to 1991 democratic principles of the organization and functioning of state power were implemented, the task of building a legal state was set" (Rybakov, 2016).

The main period of scientific and social activities of A.Zh. Maschanov took place during this difficult Soviet period of total control. For courageous statements of social and political ideas, the scientist was persecuted, accused of political illiteracy, adherence to the Islamic religion. The intellectual genius of the researcher as the driving force of the synergetic matrix for the generation of the scientist's innovative discourse (Vorozhbitova, 2020) forced A. Zh. Mashanov to develop Islamic theolinguistics, which made it possible to anticipate the distribution of Arabic studies into scholastic as the language of the Koran and artistic (as the language of artistic creativity in Arabic) (Dubinina, 2018, Tyurina, 2019). The use of the biographical method in politics allows us to reinforce statements about the ideas of A.S. Mashanov, according to the testimony of scientists and colleagues, who emphasize that under the dominance of communist ideology, it was necessary to have extraordinary courage to express such views. Therefore, we consider it natural that A. E Mashanov for a long time was persecuted by the Soviet authorities as a true Muslim, one of the few experts and interpreters of the Koran.

In his opinion, Islam is a deep concept that requires comprehensive education and humanism. The scientist expressed his understanding of Islam in the books "Tabu", "AlFarabi zhane Abay", in the manuscript "Scientific Foundations of Islam". In 1953, the newspaper Pravda published an article about K.I. Satpayev and A. Zh. Mashanov, accusing them of studying a mineral deposit. In $1956 \mathrm{~A}$. Mashanov was one of the first to raise the issue of studying the heritage of Abu Nasr al-Farabi. The scientist wrote about this in the following way: "Does anyone forbid us to study the scientific heritage of al-Farabi and is this not a direct and honorable duty of scientists of Kazakhstan - his homeland? This is our duty to the people and to the memory of one of his great sons. And I set myself the task: to start researching the legacy of al-Farabi" (Mashanov, 2017: 166). A.N. Nysanbayev emphasizes that "Mashani was the first in Kazakhstani science to pay attention to the study of the encyclopedic heritage of 
a medieval thinker, which for Kazakhstani researchers personifies the deep roots of Kazakh culture, its Turkic and Islamic origins, spiritual and moral content" (Nysanbayev, 2011).

Mashanov's contribution to changing the political process of the future consisted of: 1) predictive expressive discourse with the articulation of ideas about preserving the cultural heritage of the past; 2) imperative calls for the preservation of historical memory; 3) explanations about ethno-confessional ethics as the basis of humanistic and moral views; 5) carried out actions influencing the mood in the society; 6) developed the foundations of theolinguistics. During the years of authoritarian rule (1973) he completed the manuscript "Al-Farabi and Modern Science", which was not allowed to print by the censor. A. Mashanov did a lot of work to restore the name of al-Farabi on the Kazakh land. For this purpose, scientists made trips to Turkestan, Tashkent, Leningrad, Moscow, Ufa, Arabia, Syria. And Mashanov laid the foundations of a new science - theolinguistics during the years of stagnation. In his unpublished manuscript "Scientific Foundations of Islam", the scientist wrote that the Islamic faith is the purest religion with a scientific basis, the greatest duty of Islam is science (Zakhiyauly, 2018).

Scientists testified that their thorough knowledge of the theory of Islam A.Zh. Mashanov accumulated in the process of studying the cultural heritage of al-Farabi. He contributed to the study of the scientific foundations of Kuran-Karim from the standpoint of new approaches in modern science, interpreted the main provisions of the holy book in the context of the Turkic mentality, and introduced the Turkic world (Suyerkul, electronic resource; Toleubaev, 2006).

During the years of the authoritarian regime A.Zh. Mashanov was also persecuted. In the 80s, after the world conference dedicated to the 1100th anniversary of al-Farabi, A. Mashanov's ill-wishers made sure that the study of al-Farabi's work on the Kazakh land was consigned to oblivion, because al-Farabi is a native of Central Asia. In this regard, the study of the legacy of al-Farabi was now carried out in Uzbekistan, and this was due to the policy of the state aimed at inciting ethnic hatred between peoples. In 1975, A. Mashanov received a denunciation in which the scientist was accused of inconsistency between his views and the communist ideology and its dogmas" (Amrina, 2018).

History is known to be driven by the motives of individuals. Any person becomes a subject of politics when, self-organizing and expressing his views, he finds himself in 
confrontation with other social groups (with power during the period of actualization of totalitarian and authoritarian regimes), comes into conflict with the power that exists at one time or another of the scientist's activity. In this case, the scientist enters into subject-object relations, presenting, on the one hand, as a subject expressing his views, ethical views in the process of research activities, on the other hand, as an object of influence from the authorities. Subjects and objects of politics enter into political relations. Such relationships are characterized by the presence of a certain content and form of being. The content of political relations is manifested both as a certain activity of the subjects of politics, their political behavior, and as a political process. The existence of political relations is expressed in forms and principles. Political norms and principles as a form of being of political relations are divided into political and legal (laws, decrees, bylaws, international treaties, etc.), political and moral (customs, traditions, polites, etc.) and political and religious. Through these norms, especially legal ones, politics is expressed, within the framework of these norms, political subjects' function.

A.Zh. Mashanov enters the political processes of his time as a political subject, entering political relations based on the observance of political and religious norms. The political behavior of the researcher manifested itself in open opposition to the current government by studying the work of al-Farabi, a medieval thinker and founder of the doctrine of Islam. During the times of the totalitarian regime and during the years of authoritarianism, the political processes of society did not undergo significant changes, since in the Stalinist period all political relations, processes were controlled by the state (power) and its party, which was implementing the ideological guidelines of the government. During the years of implementation of the totalitarian regime and in the years of perestroika, the construction of a democratic state (1985-1991), the political process was characterized by four features: 1) it is universal, since it covers the entire society with its influence; 2) exercise control over the actions of an individual or another person; 3) its right to make binding decisions that are considered legitimate; 4) its decisions are authoritarian-imperious.

Currently, changes in the political process are associated with the implementation of the country's course for spiritual revival, modernization of the country's political system through the study of the historical experience of the people and an increase in interest in the historical and cultural heritage of the people. Such transformations have been brewing for a 
long time, since the mid-70s, from the time when individuals raised the problem of studying the cultural heritage of the people. A. Mashanov, who was engaged in the study of the work of the medieval thinker al-Farabi, was the first to raise the question of the revival of the spiritual sources, the national roots of culture through the study of the experience of the past.

The name al-Farabi is now becoming a symbol of the spiritual culture of Kazakhstan. Therefore, A.Zh. Mashanov can be considered one of the personalities who promoted back in the 60s of the last century the idea of reviving the national culture, the idea of returning to the history of the Kazakh people. The idea, promoted for 37 years, is reflected in the modern historical process in Kazakhstan.

The role of Mashanov as an indirect political personality was manifested in the fact that he gradually, through the study of the work of al-Farabi, the return of his name to his homeland, the popularization of the thinker's ideas, the publication of monographs, articles contributed to the passing of the idea of the spiritual revival of the cultural past of the people. Such ideas, put forward by many thinkers (Abai, Shakarim, Mashhur Zhusup Kopeev, etc.), accumulated gradually, can influence the evolution of the political system and contribute to a change in the political process. Such changes, which are not related to the direct political activities of individuals, indirectly influencing politics, mean the transformation of properties that do not affect the basic structures and mechanisms of power (for example, leaders, governments, individual institutions may change, but the leading values, norms, ways of governing power remain in the previous quality), and the modification of the bearing, basic elements, which together contribute to the achievement of a new quality state by the system.

Changes made to the political process of the country by such "occasional personalities" as A. Mashanov do not represent cardinal transformations in politics but relate to changes in the spiritual sphere of society. But they help to move the political process. The gradual accumulation of external and internal changes in the political system leads to the renewal of the political process. And this is due to the resonant coordination of the interests and goals of individual groups, people, parties, organizations that create the dynamism of the political process. 
The political system is a self-organizing, open and dynamic system, characterized, on the one hand, by stability, on the other - by dynamism. It is the combination of stability and dynamism of the political system that ensures the change in the political process.

\section{Conclusion}

The historical personality imposes a certain "seal" on the social processes, at the head of which it stands. An outstanding personality accelerates the course of events. The power of the influence of a talented person on the course of history development is so great that it gives rise to the erroneous opinion among people that the entire course of historical events depends entirely on it. G. V. Plekhanov called such a phenomenon "optical deception". In this regard, the role of an outstanding person cannot be overestimated since no person is able to change the course of history (Plekhanov, 1938). Historical practice shows that those historical figures who did not consider the objective laws of history, with the urgent problems of society, inevitably failed.

Applying the principles of heterogeneity and openness "any manifestation of political disagreement was ruthlessly eliminated and rooted out. This is the main rule for the functioning of a totalitarian regime" (Petrov, 2011: 15). During this period, A.Zh. Mashanov could not openly express his convictions regarding the study of the cultural heritage of the people, the revival of the spiritual experience of the past (the study of the monuments and culture of the Kazakh people, the study of the heritage of al-Farabi). All statements of the scientist were criticized, denunciations were written against A. Mashanov, the approval of the doctoral dissertation was delayed. According to the archival data of the Russian Federation, fund R 9506, op. 6a, d. 248, it is known that the motion to award A.Zh. Mashanov's degree in geological and mineralogical sciences was rejected (October 11, 1947). In document 249 there is information about the denunciation of A. Mashanov, received from geologists and young scientists of Kazakhstan. However, A. Mashanov did not stop his research on the work of al-Farabi. It was during the years of stagnation that he, in search of traces of al-Farabi in the Kazakh and Arab lands, made repeated trips abroad at his own expense, corresponded with leading scientific foundations in France, Moscow and other countries and cities, openly visited the mosque and expressed his views on the purity and scientific nature of Islamic teachings. These speeches by A. Mashanov and other leading 
figures, scientists (K. Satpayev, M. Auezov, O. Suleimenov and others) contributed to the manifestation of the nonlinear thinking of the citizens of the USSR. The gradual accumulation of episodic, not entirely open speeches of individual scientists and the intelligentsia led to the destruction of the stability of the political system. Although under the rule of totalitarian and authoritarian regimes, stability in politics was recognized as order in the political system of the state. The open speeches of the citizens of the union republics (Latvia, Georgia, Kazakhstan, etc.) were the action that led to the explosion: the dismantling of the old political system and the formation of independent states.

In the ideological and political system of views of A.Zh. Mashanov also shows signs of self-organization and dynamism. In the initial period of his scientific career, the scientist, like all citizens of the USSR, took a compulsory part in politics, but gradually, as interest in the heritage of al-Farabi manifested itself, the study of his works, the study of his worldview in the scientist, a protest was brewing against the existing political system, which prohibited freedom of thought, to engage in scientific research on the historical origins, national culture of the people. The role of A.Zh. Mashanov is great in the political process of Kazakhstan since he acted as one of the catalysts for the spiritual renewal of the country's political system.

Thus, the analysis of the historical and political activities of A.Zh. Mashanova showed that the scientists carried out many-sided activities: along with the main, geological and mineralogical activities, he was engaged in historical research, studying not only architectural monuments, but also exploring the work of the medieval thinker al-Farabi. A.Zh. Mashanov in his political activities of an indirect nature is due to his selfless activities in the name of restoring the name and cultural and historical heritage of al-Farabi. The influence of A.Zh. Mashanova as a "political personality by chance" for forty years led during the period of democracy and functioning of independent Kazakhstan to the realization of the need to study the cultural heritage, past, ethical views of the people.

The revealed process of objective " selection "of specific historical figures allows us to recognize the thesis of the" neutrality " of replacing one historical character (actor) with another for the course of social development as untenable.

An outstanding historical person is not alone, there are certain social forces behind her, on which she relies and interests which it expresses and protects. The role of the 
individual is directly dependent on the degree of activity, and, most importantly, the historical perspective of the social community on which it relies (Zimina, 2009).

Whenever the conditions for a certain historical discovery arise before society technical, social, scientific, cultural - there are people who carry them out. The more clearly a person realizes and fully expresses the need for certain changes and actions, the greater is his role and the more significant is his contribution to the treasury of world culture. Only such an outstanding person is truly free, she consciously recognizes the surrounding historical necessity and implements it in the interests of the entire people and even humanity.

\section{References}

Adulova E.S. (2009). Synergetic features of political processes: author. diss. Cand. polit. sciences. - M., 2009, 27 p.

Amrina MS (2018). Scientific and spiritual heritage of Akzhan Mashanov, Bulletin of Karaganda University,Series "History", (91), 2018, 103-110.

Barabash V.V., Kotelenets Elena A., Karabulatova Irina S., Lavrentyeva Maria Y., Mitina Yulia S. (2019). The confrontation between the Eastern and Western worldviews in the conceptual space of the information war against Russia: the genesis and evolution of the terminological apparatus. Amazonia Investiga, 2019, 8, 19: 246 - 254.

Central State Archives of the Republic of Kazakhstan, fund 2285, file, 5, sheet 12.

Central State Archives of the Republic of Kazakhstan, Fund 2285, inventory 1, file 152

Derbisaliev A. (1996). Moral life, Kazakh literature, 1996, September 17, 38.

Dubinina, N.V. (2018). Transformation of the secondary linguistic personality of an Arabist student in the academic Arabic-language discourse: abstract of thesis. ... candidate of philological sciences: 02/10/19 / Dubinina Natalya Valentinovna; [Place of protection: Adyg. state un-t]. - Maykop, 2018, $28 \mathrm{p}$.

Goncharov P.K. (2018). Politicheskiy protsess: sushchnost' i soderzhaniye. Sotsial'nogumanitarnyye znaniya, 2018, 5, $86-86$.

Gorbunova A. (2012). Political science: political institutions, processes and technologies [Text]: textbook for graduate students and students / [A. A. Gorbunov and others], Moscow: Socio-political thought, 2012, 933.

Grushevskaya, E.S., Karabulatova, I.S., Fanyan, N.Yu., Zelenskaya, V.V., Golubtsov, S.A. (20218). Linguistic and Cultural Characteristics of Virtual Discourse in the Modern Electronic and Digital Society. Interciencia Journal, 2018, 43 (8), 194-207. 
Karabulatova I., Vildanov Kh., Zinchenko A., Vasilishina E., Vassilenko A. (2017). Problems of transformation matrices modern multicultural identity of the person in the variability of the discourse of identity Electronic Information Society. Pertanika Journal of Social Science \& Humanities, 2017, 25(S), 1-16.

Karabulatova I. S., Lyausheva S.A., Nagoy A.A., Rozhkov A.A., Studenikina E.S. (2018). The problem of "OUR/OTHERS" in the discourse of intercultural communication and the new challenges of globalization and migration, Interciencia Journal, 2018, 43 (8), pp.177-192.

Karabulatova, Irina (2020). Possibilities of artificial intelligence in assessing the impact of potentially dangerous texts in modern news discourse: problem of statement Published online: 24 December 2020. International Scientific Forum "Issues of Modern Linguistics and the Study of Foreign Languages in the Era of Artificial Intelligence (dedicated to World Science Day for Peace and Development)" (LLT Forum 2020) Volume 88, 2020 DOI https://doi.org/10.1051/shsconf/20208801001

Kazakov E. F. (2017). History as a person's search for self-identity. Bulletin of KemSU. 2017. No. 2 (70). URL: https://cyberleninka.ru/article/n/istoriya-kak-poisk-chelovekomsamoidentichnosti (accessed: 24.07.2021).

Khachmafova Z.R., Karabulatova I.S., Serebryakova S.V., Zinkovskaya A.V., Ermakova E.N. (2017). The Specifics of an Estimate discourse of gender stereotypes in small forms of Folklore in a Network Discourse of Electronic and Information society at the Beginning of 2lct Century. Pertanika Journal of Social Science \& Humanities, 2017, 25 (S),137-15.

Kuhn, T.S. (1957). The Copernican Revolution. Cambridge: Harvard University Press, 1957.

Mashanov A. (2006). Earth cheese. Land construction. Kazakhstan's stone is the heritage of the Bronze Age. 3 books, Almaty: Alatau Publishing House, 2006, 288 p.

Mashanov A. (2017). Moral life, Almaty: Kazakh University, 2017, 312

Malevinsky, S. O., Sultan Aziz, A., Karabulatova, I. S., Luchinskiy, Y. V., Fanyan, N. Y., Grushevskaya, E. S., \& Zelenskay, V. V. (2019). Main types of values of full-numerication words. Religación. Revista De Ciencias Sociales Y Humanidades, 2019, 4(16), 156-163.

Nurpeisova M. (2016). Mashanov's scientific school / in Chinese, Kazakh, English and Russian, Almaty: Iskander, 2016, 223.

Nurpeisova M., Toleuov B. Akzhan Dzhaksybekovich Al-Mashani, electronic resource: http // agebirontal.kz / authors / view / 2528

Nysanbaev A.N. (2011).The development of Farabi studies in Kazakhstan: results, problems and prospects, Problems of Philosophy, 2011.

Ostrovskaya T.A., Karabulatova I.S., Khachmafova Z.R., Lyaucheva S.A., Osipov G.V. (2015).The Discourse of the Russian Elite in the ERA "Liquid" Modernity as a Problem of 


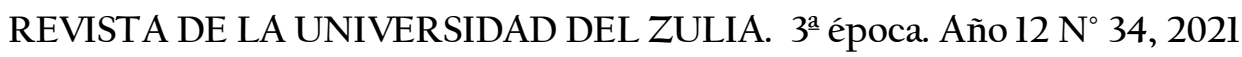
Anara G. Shabambaeva et al.// The influence of a passionate personality on the preservation, 512-534 DOI: http://dx.doi.org/10.46925//rdluz.34.28

Ethnic, Social and Cultural Security. Mediterranean Journal of Social Science, 2015, 6, 3, S4, 147154.

Parra Contreras, Reyber (2020). Historia, verdad e ideología: sobre la historia oficial de Venezuela, Revista de la Universidad del Zulia, Año $11 \mathrm{~N}^{\circ}$ 31, 2020, 3-7. DOI: https://doi.org/10.46925//rdluz.31.01

Petrov A.V. (2011). Totalitarianism: Lessons from the Past. - Irkutsk. - Publishing house of ISU, 2011, $136 \mathrm{p}$.

Plekhanov G. V. (1938). On the question of the role of personality in history. Under the banner of Marxism, 1938, 3-12. https://docviewer.yandex.ru/view/0/?page=2\& $\varepsilon^{*}=$ mw8mehF\%2BRjfp8KvGYe5jBiYoi 8p7InV ybCI6Imh0dHA6Ly9ubHIucnUvZG9tcGxla2hhbm92YS9kZXAvYXJOdXBsb2FkL2RwL2 FydGljbGUvNDAvTkEyNzk2OS5wZGYiLCJOaXRsZSI6Ik5BMjc5NjkucGRmIiwibm9pZ nJhbWUiOnRydWUsInVpZCI6IjAiLCJOcyI6MTYyNzElOTAzMjIOOSwieXUiOiI3NjAlM DUzNTAxNTgxOTQ2MTAxIiwic2VycFBhcmFtcyI6InRtPTE2MjcxNTkwMjcmdGxkPXI lJmxhbmc9cnUmbmFtZT1OQTI3OTY5LnBkZiZ0ZXh0PSVEMCU5My4lRDAlOTIuJUQ wJTlGJUQwJUJCJUQwJUIlJUQxJTglJUQwJUIwJUQwJUJEJUQwJUJFJUQwJUIyLislR DAlOUErJUQwJUIyJUQwJUJFJUQwJUJGJUQxJTgwJUQwJUJFJUQxJTgxJUQxJTgzKy VEMCVCRSsIRDElODAlRDAlQkUlRDAlQkIlRDAlQjgrJUQwJUJCJUQwJUI4JUQxJTg3 JUQwJUJEJUQwJUJFJUQxJTgxJUQxJTgyJUQwJUI4KyVEMCVCMislRDAlQjglRDElO DElRDElODIlRDAlQkUlRDElODAlRDAlQjglRDAlQjgmdXJsPWhOdHAlMOEvL25sci5yd S9kb2lwbGVraGFub3ZhL2RlcC9hcnRlcGxvYWQvZHAvYXJ0aWNsZS80MC9OQTI3O TY5LnBkZiZscjOyMTMmbWltZTlwZGYmbDEwbjlydSZzaWduPTRINzBlMDgxZjBiZG Y3YzJjYzcyMDdlMDlkNGQ2NTZlJmtleW5vPTAifQ\%3D\%3D\&lang=ru

Rybakov V.A. (2016). The Soviet state: the evolution of the political regime, Bulletin of Omsk University, 2016, 3 (48), 32-38.

Sidney Hook(ed) (1963). Philosophy and History a Symposium. Sidney Hook. New York University Press, 1963.

Shcheglov I.A. (2012). The problem of a political person in the theory of political socialization. Theory and practice of socialdevelopment, 2012, 191-194.

Shulman E. (2015). Practical political science. A guide to dealing with reality. M .: AST, 2015, $237 \mathrm{p}$.

Suyerkul B. M. Study of the language of medieval written monuments: theolinguistic aspect // https://tbi.kz/wp-content/uploads/2018/11/Suyerkul-BM ASPECT.pdf

Tyurina S. (2019). Development of communicative potential of personality by means of foreign media discourse in digital environment. Mediaobrazovanie. 2019, 2, 328 - 336.

Tuleubaev E. Akzhan Mashani and Kazakh worldview, Central Kazakhstan, 2006. 
Zakhiyauly D.S. (2018). On the views of Akzhan Mashanov on the ancient history of Kazakhstan, Bulletin of the University of Karaganda, 2018, electronic resource: https://articlekz.com/en/article/29618

Zimina I. S. (2009). Psychological and pedagogical diagnostics of passionary personality traits in children, Siberian Journal of Psychology. 2009, 33. URL: https://cyberleninka.ru/article/n/psihologo-pedagogicheskaya-diagnostika-passionarnyhkachestv-lichnosti-u-detey (date accessed: 15.04.2021).

Vorozhbitova, A., Karabulatova, I., Bzegezheva, Z., Druzhinina, V., \& Pyankova, T. (2019). A glossy magazine discourse of the early twenty-first century as a tool of globalization: Sochi school of linguistics and rhetoric. Amazonia Investiga, 8(24), 170-180.

Vorozhbitova A.A. (2020). Linguistic paradigm as a synergetic matrix for generating an innovative discourse of a collegial linguistic personality of a humanities scientist. In the collection: Fundamental problems of the humanities: experience and prospects for the development of research projects of the RFBR. Materials of the All-Russian Scientific Conference with International Participation. Scientific editor N.A. Matveeva. Resp. editor T.P. Sukhoterin. 2020.S. 212-217.

Weber M. (1990). Selected Works. - M .: Education, p. 644-706 